\title{
Removal of Heavy Metals from Chithrapuzha River Water by Iron Oxide Nanoparticles Prepared Via Green Synthesis Methods
}

\author{
G. DEEPA ${ }^{1,2}$, M. JEYARAJ ${ }^{3 *}$ and P. N. MAGUDESWARAN ${ }^{4 *}$ \\ ${ }^{1}$ Research and Development Centre, Bharathiar University, Coimbatore - 641 046, Tamil Nadu, India. \\ ${ }^{2}$ Department of Chemistry, MES College of Engineering Kuttippuram, - 679 573, Kerala, India. \\ ${ }^{3}$ Department of Chemistry, Sri Krishna College of Engineering and Technology, Coimbatore-641 008, \\ Tamil Nadu, India. \\ ${ }^{4}$ Department of Chemistry, Hindusthan College of Engineering and Technology, Coimbatore-641 032, \\ Tamil Nadu, India. \\ ${ }^{*}$ Corresponding author E-mail: jeyaraja100@gmail.com
}

http://dx.doi.org/10.13005/ojc/360620

(Received: August 22, 2020; Accepted: November 11, 2020)

\begin{abstract}
On account of industrialization and increasing population, the water bodies get polluted by means of degradable and non-degradable substances. In $21^{\text {st }}$ century, it is necessary to maintain a healthy environment especially water bodies for the survival of not the aquatic animals but also for healthy human life. Recent advances suggest that the issues related to water quality could be resolved by using nanoparticles and nano-filtration membrane methods from the development of nanotechnology. In this research, attempt to remove heavy metals from Chithrapuzha River water at Cochin bar mouth $\left(\mathrm{S}_{1}\right)$ and Fact barge jetty $\left(\mathrm{S}_{2}\right)$ using $\mathrm{Fe}_{2} \mathrm{O}_{3}$ prepared via green synthesis using Egg albumin and Aloe vera. Our results provoke that, the synthesis of $\mathrm{Fe}_{2} \mathrm{O}_{3}$ nanoparticle is costeffective and eco-friendly and also good in nano-regime. Results of filtration studies showed that $\mathrm{Fe}_{2} \mathrm{O}_{3}$ nanoparticles remove heavy metals from Chithrapuzha River water and also increases the $\mathrm{DO}$ content which helps the survival of aquatic life.
\end{abstract}

Keywords: $\mathrm{Fe}_{2} \mathrm{O}_{3}$ nanoparticles, Chithrapuzha River, Heavy Metals, Egg albumin, Aloe vera.

\section{INTRODUCTION}

Water has played the crucial role in the evolution of life from molecules to man. The adverse effect of water pollution is a major environmental concern on both nature and human beings. In recent years global concern for the quality and quantity of river water has increased. The water quality of river has been considerably influenced by the discharge of industrial and domestic wastewaters besides agricultural runoff. Moreover, the large quantity of various wastewaters discharged into the river not only influences the aquatic organisms and also alters the quality of the environment.

As for as $21^{\text {st }}$ century is concerned, it is most urgent to take necessary steps to control water pollution to give pure water for future purpose.

This is an Open Access article licensed under a Creative Commons license: Attribution 4.0 International (CC- BY). Published by Oriental Scientific Publishing Company @ 2018

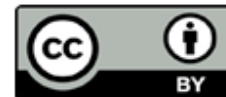


Various techniques like adsorption, bio-sorption precipitation, electrochemical treatments, reverse osmosis, evaporation, membrane filtration, oxidation, flotation and ion exchange processes are commonly used $^{1-3}$. Among these, adsorption is an efficient and conventional method to remove toxic metal ions and bacterial pathogens from water.

Green synthesis of metal and metal oxide nanoparticles has been a highly gorgeous research area over the last decade. The development of novel and cost-effective nanomaterials for pollution detection, environmental remediation and other applications has attracted considerable attention. From the review of literature, it was found that the issues related to water quality could be resolved by using nanoparticles and nano-filtration membrane methods $^{4-5}$.

Because of their increased reactivity and property changes, the nanoparticles play a important role in chemical and transformation cycling. The increased reactivity of nanoparticles is mainly due to the larger surface to volume ratio as compared to the bulk materials. Nano-sized metal oxides are expected to play an important role as efficient adsorbents as they have high surface areas and a large surface to volume ratio compared with conventional sorbents. Nano-sized metal oxides are highly valued material with various applications in electrical, optical, catalysts, gas sensors, mechanical devices, sunscreens and cosmetics ${ }^{6-9}$.

\section{Study area}

The aim of this research to determine the associations between different sized nanoparticles and toxic trace metals present in a polluted Chithrapuzha River system in Kerala. The River Chitrapuzha is one of the tributaries of Periyar River and passes through Amabalamedu, Kochi area, on the southern coast of the Indian subcontinent. The river receives a variety of effluents from refinery, fertilizer and other chemical related industries such as Fertilizers and Chemicals Travancore (FACT), Hindustan Organics Chemicals Limited (HOCL) and Kochi Refinery Limited (KRL) are located in and around Chitrapuzha River. The effluent mainly contains ammonium related compounds such as ammonium sulphate, ammonium phosphate and calcium sulphate, nitrate and heavy metals. The total effluent discharge into river is about $33,600 \mathrm{~m}^{3}$ per day.

The water samples was collected from Chithrapuza River at Cochin bar mouth $\left(\mathrm{S}_{1}\right)$ and Fact barge jetty $\left(S_{2}\right)$ during rainy and summer seasons in the year 2019 and study the effect of $\mathrm{Fe}_{2} \mathrm{O}_{3}$ nano particles with two different sizes on the removal of impurities from the water. The $\mathrm{Fe}_{2} \mathrm{O}_{3}$ based nanomaterial is used to removable of heavy metals from the contaminated water because of their significant features such as large surface area, small size and magnetic property ${ }^{10-15}$. The magnetic property of $\mathrm{Fe}_{2} \mathrm{O}_{3}$ nanoparticles allows easy separation of adsorbents from the system and could be reused based on the economic burden. Thus in this research focused to study the effect of different sized $\mathrm{Fe}_{2} \mathrm{O}_{3}$ nanoparticles on the river water collected at two different places in various seasons.

\section{MATERIAL AND METHODS}

The $\mathrm{Fe}_{2} \mathrm{O}_{3}$ nanoparticles are prepared via green synthesis technique using Egg albumin and Aloe vera plant extract via microwave assisted heating method. Analytic reagent grade $\mathrm{FeCl}_{3}$ was used as precursor along with water and Egg albumin and Aloe vera plant extract separately to prepare the base solution. The solution is kept in the microwave for about $18 \mathrm{~min}$ till the solvent get evaporated. The obtained black color precipitate was centrifuged and gets dried to collect the yield. The obtained particles were calcined at $600^{\circ} \mathrm{C}$ and used for water treatment. The calcined particles were characterized for structural analysis via XRD, SEM and EDAX studies. These nanoparticles were used as a filter in sand beds of height $20 \mathrm{~cm}$ with $\mathrm{pH} 8^{16}$. The thickness of nanoparticle layer over the sand bed was maintained at 3 different thicknesses viz $2 \mathrm{~cm}, 3 \mathrm{~cm}$ and $4 \mathrm{~cm}$. After passing the river water collected from Cochin bar mouth $\left(\mathrm{S}_{1}\right)$ and Fact barge jetty $\left(S_{2}\right)$ during rainy and summer seasons through this filter medium was collected on a beaker placed over a magnet to remove $\mathrm{Fe}_{2} \mathrm{O}_{3}$ nanoparticles if any present in the filtered water. The schematic setup used in this study for the treatment of water was shown in Figure 1. 


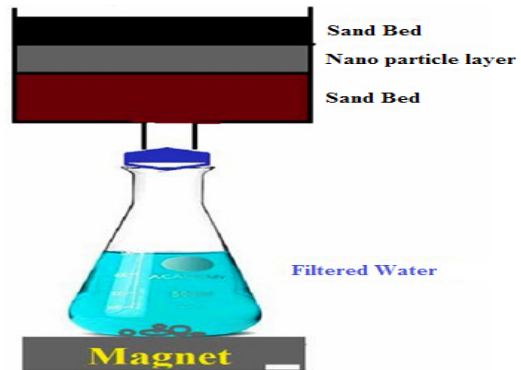

Fig. 1. Schematic setup used for water treatment

\section{RESULTS AND DISCUSSION}

\section{Analysis of Nanoparticles}

The prepared nanoparticles were structurally analyzed XRD and SEM analysis. The recorded X-ray diffraction pattern of both samples Fig. 2 resembles well with JCPDS card No: 24-0072 of $\alpha-\mathrm{Fe}_{2} \mathrm{O}_{3}$ particles with slight variation in peak positions ${ }^{17}$. The image revealed that broadening of peaks increases with Aloe vera plant which in turn reduces the particle size. Both the samples crystallize in a cubic structure. The crystallite sizes were obtained using the Debye-Scherrer formula. The obtained values 18.56 $\mathrm{nm}$ and $6.75 \mathrm{~nm}$ for the samples $A$ and $B$ confirmed their existence in nano-regime.

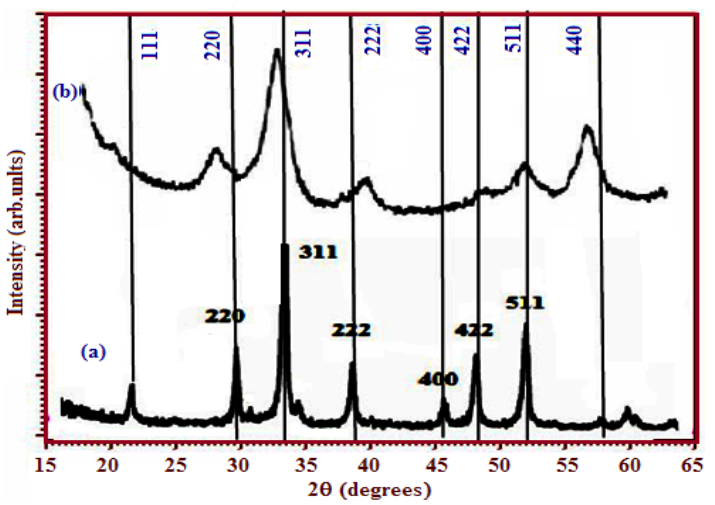

Fig. 2. Indexed PXRD patterns of $\alpha-\mathrm{Fe}_{2} \mathrm{O}_{3}$ prepared using Egg Albumien and Aloe vera plant
The morphology of the samples plays a vital role in wastewater treatment ${ }^{18}$. SEM micrographs were recorded and depicted in Fig. 3. The $\alpha-\mathrm{Fe}_{2} \mathrm{O}_{3}$ prepared via Egg albumin shows an irregular shape with agglomeration of different particle sizes with globular shapes showing both micro and macro pores and a few crevices and voids. Whereas the Aloe vera extract assisted particles are spherical in shape. Size distributions of both images were analyzed using image $\mathrm{J}$ software and from the distribution histogram, the particle size was calculated. The values obtained well matched with the size obtained from XRD.
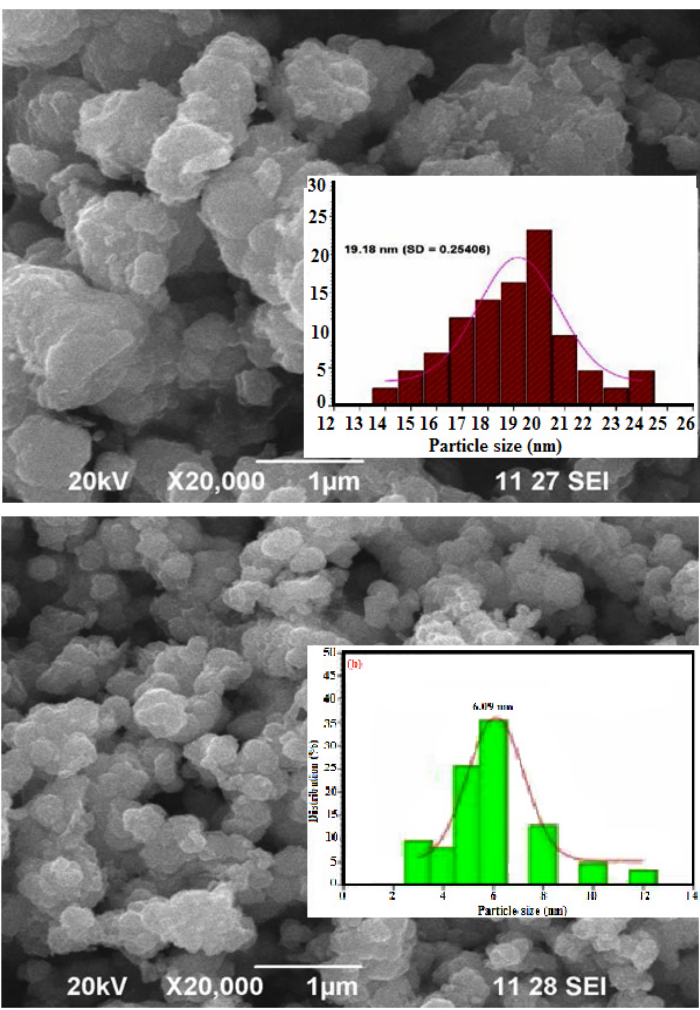

Fig. 3. SEM micrograph with an insert of particle size histogram of $\alpha-\mathrm{Fe}_{2} \mathrm{O}_{3}$ prepared using Egg albumin and Aloe vera plant

Table 1: Physico-chemical characteristics of water samples collected from Chithrapuzha River water at Cochin bar mouth $\left(S_{1}\right)$ and Fact barge jetty $\left(S_{2}\right)$ of during rainy and summer seasons (2019) before nanoparticles addition

\begin{tabular}{|c|c|c|c|c|c|}
\hline \multirow[t]{2}{*}{ Parameters } & \multirow[t]{2}{*}{ Units } & \multicolumn{2}{|c|}{ Rainy season } & \multicolumn{2}{|c|}{ Summer season } \\
\hline & & $\begin{array}{l}\text { Cochin bar } \\
\text { mouth }\left(S_{1}\right)\end{array}$ & $\begin{array}{l}\text { Fact barge } \\
\text { jetty }\left(\mathrm{aS}_{2}\right)\end{array}$ & $\begin{array}{l}\text { Cochin bar } \\
\text { mouth }\left(S_{1}\right)\end{array}$ & $\begin{array}{l}\text { Fact barge } \\
\text { jetty }\left(\mathrm{S}_{2}\right)\end{array}$ \\
\hline DO & $\%$ saturation & 93 & 90 & 92 & 88 \\
\hline $\mathrm{pH}$ & $\mathrm{pH}$ units & 6.7 & 7.8 & 6.9 & 9.5 \\
\hline BOD & $\mathrm{mg} / \mathrm{l}$ & 0.78 & 3.5 & 0.99 & 4.8 \\
\hline $\mathrm{P}$ & $\mathrm{mg} / \mathrm{l}$ & 0.02 & 1.5 & 0.09 & 2.5 \\
\hline $\mathrm{N}$ & $\mathrm{mg} / \mathrm{l}$ & 0.90 & 1.20 & 1.1 & 1.99 \\
\hline TURBIDITY & NTU & 1.85 & 10.20 & 2.42 & 12.6 \\
\hline TDS & $\mathrm{mg} / \mathrm{l}$ & 132 & 738 & 153 & 942 \\
\hline
\end{tabular}


The physico-chemical characteristics of the water samples collected from Cochin bar mouth $\left(S_{1}\right)$ and Fact barge jetty $\left(S_{2}\right)$ of Chithrapuzha River water during rainy and summer seasons in the year 2019 are given in Table 1. It is clearly indicated that the lower values of $\mathrm{DO}$ and higher values of BOD threaten the aquatic life of Chithrapuzha river water at $S_{2}$ compared to $S_{1}$. The decrease in DO values at $S_{2}$ is due to the discharge of oxygen demanding waste. Like BOD the amount of nitrogen, phosphorus, turbidity and TDS increased from $\mathrm{S}_{1}$ to $\mathrm{S}_{2}$ during both rainy and summer seasons is mainly due to discharge of untreated industrial effluents located near Chithrapuzha river at $S_{2}$. In order to increase the water quality of the river, the river water passed through $\mathrm{Fe}_{2} \mathrm{O}_{3}$ nanoparticle layer of the same three different thicknesses and analyzed the parameter after the filtration. The calculated values of physico-chemical parameters are given in Tables 2 and 3 and clearly indicate that nanoadsorbent increases the DO value whereas it decreases the $B O D$ value. Likewise, $D O$ value is more in the case of Aloe vera assisted $\mathrm{Fe}_{2} \mathrm{O}_{3}$ nanoparticles. This may be due to in addition to high specific surface areas nanoparticles also have unique adsorption properties due to different distributions of reactive surface sites and disordered surface regions. Improved values of DO are one of the insistent conditions for aquatic life. During filtration only very few particles of $\mathrm{Fe}_{2} \mathrm{O}_{3}$ nanoparticles were selected at the surface of the magnet. It is evident that the prepared nanoparticles have high surface binding energy and high internal diffusion resistance. The nanoparticles synthesized via green methods are non toxic and it won't affect the water quality. It is an eco-friendly material and can be used directly to a polluted environment with less chance of secondary pollution ${ }^{19-20}$. The graphical representation of variation of $\mathrm{BOD}$ and $\mathrm{DO}$ with the thickness of nanolayer for both $\mathrm{Fe}_{2} \mathrm{O}_{3}$ samples during rainy and summer seasons are given in Figures 4 and 5 .

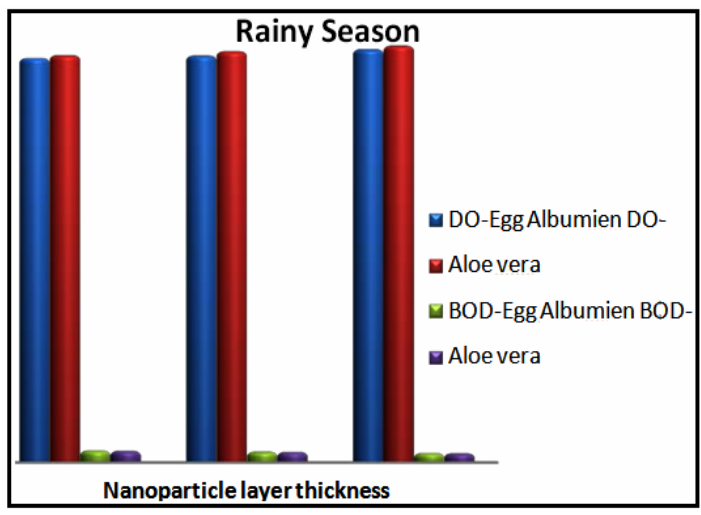

Fig. 4. Variation of BOD and DO with the thickness of Nano layer for Both $\mathrm{Fe}_{2} \mathrm{O}_{3}$ samples in rainy season

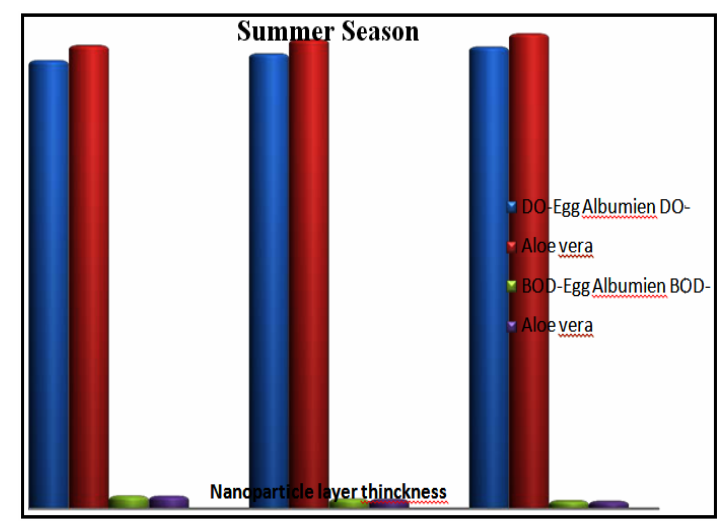

Fig. 5. Variation of $B O D$ and DO with the thickness of Nano layer for Both $\mathrm{Fe}_{2} \mathrm{O}_{3}$ samples in summer seaso

Table 2: Physico-chemical characteristics of water sample collected from Chithrapuzha River at Fact barge jetty $\left(\mathrm{S}_{2}\right)$ of during rainy and summer seasons (2019) after using Egg albumin assisted $\mathrm{Fe}_{2} \mathrm{O}_{3}$ nanoparticle filtration

\begin{tabular}{|c|c|c|c|c|c|c|c|}
\hline \multirow[t]{2}{*}{ Parameters } & \multirow[t]{2}{*}{ Units } & \multicolumn{3}{|c|}{ Rainy session $\left(\mathrm{S}_{2}\right)$} & \multicolumn{3}{|c|}{ Summer session $\left(\mathrm{S}_{2}\right)$} \\
\hline & & $\begin{array}{c}1 \mathrm{~cm} \\
\text { thick layer }\end{array}$ & $\begin{array}{c}2 \mathrm{~cm} \\
\text { thick layer }\end{array}$ & $\begin{array}{c}3 \mathrm{~cm} \\
\text { thick layer }\end{array}$ & $\begin{array}{c}1 \mathrm{~cm} \\
\text { thick layer }\end{array}$ & $\begin{array}{c}2 \mathrm{~cm} \\
\text { thick layer }\end{array}$ & $\begin{array}{c}3 \mathrm{~cm} \\
\text { thick layer }\end{array}$ \\
\hline DO & $\%$ saturation & 94.6 & 95.2 & 96.7 & 92.8 & 94.2 & 95.6 \\
\hline $\mathrm{pH}$ & $\mathrm{p}^{\mathrm{H}}$ units & 7.90 & 7.8 & 7.8 & 7.6 & 7.5 & 7.3 \\
\hline BOD & $\mathrm{mg} / \mathrm{L}$ & 2.81 & 2.54 & 2.21 & 2.72 & 2.13 & 1.75 \\
\hline $\mathrm{P}$ & $\mathrm{mg} / \mathrm{L}$ & 1.07 & 1.0 & 0.98 & 1.08 & 1.01 & 0.93 \\
\hline $\mathrm{N}$ & $\mathrm{mg} / \mathrm{L}$ & 1.3 & 1.18 & 1.09 & 1.5 & 1.8 & 2.00 \\
\hline TURBIDITY & NTU & 9.3 & 9.2 & 9.0 & 9.7 & 9.4 & 9.4 \\
\hline TDS & $\mathrm{mg} / \mathrm{L}$ & 235 & 223 & 215 & 230 & 219 & 212 \\
\hline
\end{tabular}


Table 3: Physico-chemical characteristics of water sample collected from Chithrapuzha River at Fact barge jetty $\left(\mathrm{S}_{2}\right)$ of during rainy and summer seasons (2019) after using Aloe vera assisted $\mathrm{Fe}_{2} \mathrm{O}_{3}$ nanoparticle filtration

\begin{tabular}{|c|c|c|c|c|c|c|c|}
\hline \multirow[t]{2}{*}{ Parameters } & \multirow[t]{2}{*}{ Units } & \multicolumn{3}{|c|}{ Rainy Session $\left(\mathrm{S}_{2}\right)$} & \multicolumn{3}{|c|}{ Summer Session $\left(\mathrm{S}_{2}\right)$} \\
\hline & & $\begin{array}{c}1 \mathrm{~cm} \\
\text { thick layer }\end{array}$ & $\begin{array}{c}2 \mathrm{~cm} \\
\text { thick layer }\end{array}$ & $\begin{array}{c}3 \mathrm{~cm} \\
\text { thick layer }\end{array}$ & $\begin{array}{c}1 \mathrm{~cm} \\
\text { thick layer }\end{array}$ & $\begin{array}{c}2 \mathrm{~cm} \\
\text { thick layer }\end{array}$ & $\begin{array}{c}3 \mathrm{~cm} \\
\text { thick layer }\end{array}$ \\
\hline DO & $\%$ saturation & 95.3 & 96.2 & 97.5 & 95.9 & 97.1 & 98.3 \\
\hline $\mathrm{pH}$ & $\mathrm{pH}$ units & 7.8 & 7.8 & 7.4 & 7.5 & 7.3 & 7.2 \\
\hline BOD & $\mathrm{mg} / \mathrm{L}$ & 2.73 & 2.48 & 2.15 & 2.68 & 2.04 & 1.62 \\
\hline $\mathrm{P}$ & $\mathrm{mg} / \mathrm{L}$ & 1.03 & 0.98 & 0.95 & 1.04 & 0.97 & 0.91 \\
\hline $\mathrm{N}$ & $\mathrm{mg} / \mathrm{L}$ & 1.2 & 1.05 & 1.02 & 1.0 & 0.9 & 0.82 \\
\hline TURBIDITY & NTU & 8.8 & 8.3 & 8.1 & 9.4 & 9.1 & 8.9 \\
\hline TDS & $\mathrm{mg} / \mathrm{L}$ & 228 & 217 & 209 & 218 & 207 & 197 \\
\hline
\end{tabular}

Turbidity of the water decreases with nanoparticle filtration, which means that it reduces the light scattering ability of the water, which confirms that the proposed nanoparticles highly removed the clusters of fungi and algae thus it removed micro organism from water. Nitrate imposing a serious hazard to potable water provisions and producing ecological disturbances ${ }^{21}$. Children and infants are highly sensitive to the towering levels of nitrates, which causes methemoglobinemia or blue-baby syndrome and likely formation of carcinogenic nitrosamines ${ }^{22}$. In our results, we found that lowering of nitrate concentration takes place with an increase of nano layer thickness. Thus by treating with nanoparticles, the effluent water sample was converted into a good quality.

\section{Removal of heavy metals}

Generally heavy metals are considered to be a hazard toward ecosystems and humans because of their high-potential toxicity ${ }^{23-27}$. Heavy metals such as copper, chromium, zinc, manganese and iron in very small quantities are necessary for the function of human body. But, if the metals present to a certain quantity, they can cause poisoning, resulting in severe implications to human health. Like plastics, heavy metals are non-biodegradable materials. The existence of heavy metals even at trace level is believed to be a threat to the human health and ecological environment ${ }^{28}$.

The metal analysis of Chithrapuzha River water at Cochin bar mouth $\left(\mathrm{S}_{1}\right)$ and Fact barge jetty $\left(S_{2}\right)$ during rainy and summer seasons after using Egg albumin and Aloe vera assisted $\mathrm{Fe}_{2} \mathrm{O}_{3}$ nanoparticle filtration are given in the tables from 4 to 7 and also metal analysis of Chithrapuzha River water at $S_{1}$ and $S_{2}$ during rainy and summer seasons before nano-particles addition is given in the Table 8. It is clearly indicates that $\mathrm{Fe}_{2} \mathrm{O}_{3}$ nanoparticle have received increasing attention in removing heavy metals from water. This study exhibited that the prepared Egg albumin and Aloe vera assisted $\mathrm{Fe}_{2} \mathrm{O}_{3}$ nanoparticles can be used as an alternate to the traditional adsorbents methods for the removal of heavy metal ions from Chithrapuzha River water at $S_{1}$ and $S_{2}$ with high removal efficiency within a very short time. The removal of heavy metals like cadmium, copper, lead, zinc, chromium and iron as typical metal ions present in wastewater, by adsorption onto $\mathrm{Fe}_{2} \mathrm{O}_{3}$ nanoparticles was successfully accomplished. Adsorption was very fast and equilibrium was attained within 15-20 minutes. It also indicated that adsorption was highly dependent on the initial concentration of heavy metals present in the water samples.

Table 4: Metal analysis of Chithrapuzha River water at Cochin bar mouth (S1) during rainy and summer seasons-2019 after using Egg albumin assisted $\mathrm{Fe}_{2} \mathrm{O}_{3}$ nanoparticle filtration

\begin{tabular}{|c|c|c|c|c|c|c|}
\hline \multirow[t]{2}{*}{ Metals analyzed in $\mathrm{mg} / \mathrm{L}$} & \multicolumn{3}{|c|}{ Rainy Session $\left(\mathrm{S}_{1}\right)$} & \multicolumn{3}{|c|}{ Summer Session $\left(\mathrm{S}_{1}\right)$} \\
\hline & $\begin{array}{c}1 \mathrm{~cm} \\
\text { thick layer }\end{array}$ & $\begin{array}{c}2 \mathrm{~cm} \\
\text { thick layer }\end{array}$ & $\begin{array}{c}3 \mathrm{~cm} \\
\text { thick layer }\end{array}$ & $\begin{array}{c}3 \mathrm{~cm} \\
\text { thick layer }\end{array}$ & $\begin{array}{c}1 \mathrm{~cm} \\
\text { thick layer }\end{array}$ & $\begin{array}{l}2 \mathrm{~cm} \\
\text { thick layer }\end{array}$ \\
\hline Cadmium & 0.39 & 0.32 & 0.29 & 0.76 & 0.72 & 0.68 \\
\hline Copper & 0.11 & 0.09 & 0.06 & 0.3 & 0.29 & 0.26 \\
\hline Lead & 2.47 & 2.41 & 2.39 & 1.81 & 1.72 & 1.52 \\
\hline Zinc & 4.89 & 4.81 & 4.72 & 2.18 & 2.06 & 1.72 \\
\hline Chromium & 1.19 & 1.11 & 1.03 & 0.42 & 0.38 & 0.32 \\
\hline Iron & 0.72 & 0.68 & 0.52 & 0.46 & 0.23 & 0.1 \\
\hline
\end{tabular}


Table 5: Metal analysis of Chithrapuzha River water at Cochin bar mouth $\left(\mathrm{S}_{1}\right)$ during rainy and summer seasons-2019 after using Aloe vera assisted $\mathrm{Fe}_{2} \mathrm{O}_{3}$ nanoparticle filtration

\begin{tabular}{|c|c|c|c|c|c|c|}
\hline \multirow[t]{2}{*}{ Metals analyzed in $\mathrm{mg} / \mathrm{L}$} & \multicolumn{3}{|c|}{ Rainy Session $\left(\mathrm{S}_{1}\right)$} & \multicolumn{3}{|c|}{ Summer Session $\left(\mathrm{S}_{1}\right)$} \\
\hline & $\begin{array}{c}1 \mathrm{~cm} \\
\text { thick layer }\end{array}$ & $\begin{array}{c}2 \mathrm{~cm} \\
\text { thick layer }\end{array}$ & $\begin{array}{c}3 \mathrm{~cm} \\
\text { thick layer }\end{array}$ & $\begin{array}{c}1 \mathrm{~cm} \\
\text { thick layer }\end{array}$ & $\begin{array}{c}2 \mathrm{~cm} \\
\text { thick layer }\end{array}$ & $\begin{array}{c}3 \mathrm{~cm} \\
\text { thick layer }\end{array}$ \\
\hline Cadmium & 0.47 & 0.46 & 0.45 & 0.8 & 0.78 & 0.77 \\
\hline Copper & 0.17 & 0.16 & 0.14 & 0.31 & 0.30 & 0.29 \\
\hline Lead & 2.50 & 2.49 & 2.47 & 1.82 & 1.80 & 1.79 \\
\hline Zinc & 4.90 & 4.88 & 4.83 & 2.34 & 2.31 & 2.29 \\
\hline Chromium & 1.26 & 1.23 & 1.20 & 0.47 & 0.45 & 0.44 \\
\hline Iron & 0.86 & 0.84 & 0.78 & 0.45 & 0.43 & 0.42 \\
\hline
\end{tabular}

Table 6: Metal analysis of Chithrapuzha River water at Fact barge jetty $\left(S_{2}\right)$ during rainy and summer seasons-2019 after using Egg Albumin assisted $\mathrm{Fe}_{2} \mathrm{O}_{3}$ nanoparticle filtration

\begin{tabular}{|c|c|c|c|c|c|c|}
\hline \multirow[t]{2}{*}{ Metals analyzed in $\mathrm{mg} / \mathrm{L}$} & \multicolumn{3}{|c|}{ Rainy Session $\left(\mathrm{S}_{2}\right)$} & \multicolumn{3}{|c|}{ Summer Session $\left(\mathrm{S}_{2}\right)$} \\
\hline & $\begin{array}{c}1 \mathrm{~cm} \\
\text { thick layer }\end{array}$ & $\begin{array}{c}2 \mathrm{~cm} \\
\text { thick layer }\end{array}$ & $\begin{array}{c}3 \mathrm{~cm} \\
\text { thick layer }\end{array}$ & $\begin{array}{c}1 \mathrm{~cm} \\
\text { thick layer }\end{array}$ & $\begin{array}{c}2 \mathrm{~cm} \\
\text { thick layer }\end{array}$ & $\begin{array}{c}3 \mathrm{~cm} \\
\text { thick layer }\end{array}$ \\
\hline Cadmium & 0.88 & 0.85 & 0.8 & 1.75 & 1.7 & 1.68 \\
\hline Copper & 1.68 & 1.61 & 1.59 & 3.89 & 3.82 & 3.79 \\
\hline Lead & 6.47 & 6.39 & 6.29 & 5.6 & 5.52 & 5.42 \\
\hline Zinc & 10.01 & 9.4 & 8.9 & 7.75 & 7.69 & 7.51 \\
\hline Chromium & 2.39 & 2.32 & 2.29 & 0.88 & 0.82 & 0.78 \\
\hline Iron & 2.6 & 2.56 & 2.5 & 1.89 & 1.83 & 1.8 \\
\hline
\end{tabular}

Table 7: Metal analysis of Chithrapuzha River water at Fact barge jetty $\left(\mathrm{S}_{2}\right)$ during rainy and summer seasons-2019 after using Aloe vera assisted $\mathrm{Fe}_{2} \mathrm{O}_{3}$ nanoparticle filtration

\begin{tabular}{|c|c|c|c|c|c|c|}
\hline \multirow[t]{2}{*}{ Metals analyzed in $\mathrm{mg} / \mathrm{L}$} & \multicolumn{3}{|c|}{ Rainy Session $\left(\mathrm{S}_{2}\right)$} & \multicolumn{3}{|c|}{ Summer Session $\left(\mathrm{S}_{2}\right)$} \\
\hline & $\begin{array}{c}1 \mathrm{~cm} \\
\text { thick layer }\end{array}$ & $\begin{array}{l}2 \mathrm{~cm} \\
\text { thick layer }\end{array}$ & $\begin{array}{c}3 \mathrm{~cm} \\
\text { thick layer }\end{array}$ & $\begin{array}{c}1 \mathrm{~cm} \\
\text { thick layer }\end{array}$ & $\begin{array}{c}2 \mathrm{~cm} \\
\text { thick layer }\end{array}$ & $\begin{array}{c}3 \mathrm{~cm} \\
\text { thick layer }\end{array}$ \\
\hline Cadmium & 0.90 & 0.88 & 0.82 & 1.78 & 1.74 & 1.7 \\
\hline Copper & 1.70 & 1.68 & 1.65 & 3.90 & 3.88 & 3.83 \\
\hline Lead & 6.45 & 6.40 & 6.39 & 5.62 & 5.54 & 5.50 \\
\hline Zinc & 10.5 & 10.1 & 9.8 & 7.80 & 7.78 & 7.63 \\
\hline Chromium & 2.40 & 2.37 & 2.30 & 0.89 & 0.82 & 0.78 \\
\hline Iron & 2.6 & 2.56 & 2.5 & 1.89 & 1.81 & 1.76 \\
\hline
\end{tabular}

Table 8: Metal analysis of Chithrapuzha River water before nanoparticles addition

\begin{tabular}{|c|c|c|c|c|}
\hline \multirow[t]{2}{*}{ Metals analyzed in $\mathrm{mg} / \mathrm{L}$} & \multicolumn{2}{|c|}{ Rainy Session } & \multicolumn{2}{|c|}{ Summer Session } \\
\hline & Cochin bar mouth $\left(\mathrm{S}_{1}\right)$ & Fact barge jetty $\left(\mathrm{S}_{2}\right)$ & Cochin bar mouth $\left(\mathrm{S}_{1}\right)$ & Fact barge jetty $\left(\mathrm{S}_{2}\right)$ \\
\hline Cadmium & 0.48 & 0.92 & 0.82 & 1.80 \\
\hline Copper & 0.18 & 1.80 & 0.32 & 3.90 \\
\hline Lead & 2.51 & 6.50 & 1.84 & 5.68 \\
\hline Zinc & 4.92 & 10.8 & 2.38 & 7.82 \\
\hline Chromium & 1.28 & 3.62 & 1.60 & 4.85 \\
\hline Iron & 0.88 & 2.68 & 0.46 & 1.93 \\
\hline
\end{tabular}

\section{CONCLUSION}

The water samples collected from Chithrapuzha River at Fact barge jetty $\left(\mathrm{S}_{1}\right)$ was highly contaminated when compared to Cochin bar mouth $\left(S_{1}\right)$ during both rainy and summer seasons.
Nanomaterials have been extensively used to remove heavy metals in water due to their unique properties. In this work, $\mathrm{Fe}_{2} \mathrm{O}_{3}$ nano-particles via green synthesis using Egg albumin and Aloe vera which reduces the toxicity of prepared particles. The results showed that the improved values of DO and 
reduced values of $B O D$ confirm the high adsorption of the prepared $\mathrm{Fe}_{2} \mathrm{O}_{3}$ nanoparticles. Likewise the iron oxide nanoparticles used for the removal of heavy metals from the water systems developed as well efficient and cost-effective nanoadsorbent. These nanomaterials exhibit great advantages as adsorbents not only towards heavy metals and also due to less particle size, Egg albumin and Aloe vera assisted $\mathrm{Fe}_{2} \mathrm{O}_{3}$ nanoparticles showed many improvements in water quality parameters on both seasons.

\section{ACKNOWLEDGEMENT}

None.

\section{Conflict of interest}

The authors declare that there is no conflict of interests regarding the publication of this paper.

\section{REFERENCES}

1. Bakkaloglu, I.; Butter, T. J.; Evison, L. M.; Holland, I. C. Water Sci. Technol., 1998, 38, 268-277.

2. Gunatilake, S. K. J. Multidiscip. Eng. Sci. Stud., 2015, 1(1), 12-18.

3. Sörme, L.; Lagerkvist, R. Sci. Total Environ., 2002, 298(1), 131-145.

4. Savage, N.; Diallo, M. S. J. Nanopart. Res., 2005, 7, 331-342.

5. Aorkas, M.; Tsiourvas, D.; Paleos, C. M. Chem. Mater., 2003, 15(14), 2844-2847.

6. Lu, H.; Wang, J.; Stoller, M.; Wang, T.; Bao, Y.; Hao, H. Adv. Mater. Sci. Eng., 2016,http:// dx.doi.org/10.1155/2016/4964828.

7. Sun, Y. F.; Liu, S. B.; Meng, F. L.; Liu, J. Y.; Jin, Z.; Kong, L. T.; Liu, J. H. Sensors., 2012, 12(3), 2610-2631.

8. Wang, X.; Cao, R.; Zhang, S.; Hou, P.; Han, R.; Shao, M.; Xu, X. J. Mater. Chem. A., 2017, 45, 23999-24010.

9. Lu, P. J.; Fang, S.W.; Cheng, W. L.; Huang, S. C.; Huang, M. C.; Cheng, H. F. J. Food. Drug. Anal., 2018, 26, 1193-1200.

10. Pragnesh, N. D.; Chopda, L. V. J. Nanotechnol., 2014, 1, 1-14.http://dx.doi.org/10.1155/ 2014 /398569.

11. Xu, P.; Zeng, G. M.; Huang, D. L.; Feng, C. L.; Hu, S.; Zhao, M. H.; Liu, Z. F. Sci. Total. Environ., 2012, 424, 1-10.

12. Warner, C. L.; Chouyyok, W.; Mackie, K. E.; Neinar, D.; Saraf, L. V.; Droubay, T. C.; Warner, M. G.; Addlemen, R. S. Langmuir., 2012, 28(8), 3931-3937.

13. Karatapanis, A. E.; Petrakis, D. E.; Stalikas, C. D. Anal. Chim. Acta., 2012, 726, 22-27.
14. Yang, H.; Tian, Z.; Wang, J.; Yang, S. Sensor Actuat B-Chem., 2012, 161(1), 429-433.

15. Teja, A. S.; Koh, P.Y. Prog. Cryst. Growth. Ch., 2009, 55, 22-45.

16. Subha, V.; Divya, K.; Gayathri, S.; Jagan Mohan, E.; Keerthanaa, N.; Vinitha, M.; Kirubanandan, S.; Renganathan, S. Drug Des. Dev. Ther., 2018, 2(5), 178-184.

17. Joya1, M. R.; Bar'on-Jaimez, J.; BarbaOrtega, J. J. Phys. Conf. Ser., 2013, 466, 012004. http://dx.doi.org/10.1088/1742-6596/ 466/1/012004

18. Naidoo, S.; Olaniran, A. O. Int. J. Environ. Res. Public Health., 2014, 11(1), 249-270.

19. Liu,Y.; Chen, X.; Li, J.;Burda, C. Chemosphere., 2005, 61(1), 11-18.

20. Liu, Y.; Wang, X.; Yang, F.; Yang, X. Micropor. Mesopor. Mat., 2008, 114(1), 431-439.

21. Nasreen, S.; Rafique, U. Int. J. Chem. Environ. Eng., 2012, 3(5), 355-361.

22. Majumdar, D.; Gupta, N. Indian J. Environ. Health., 2000, 42, 28-39.

23. Zhou, D.; Zhang, L.; Zhou, J.; Guo, S. Water Res., 2004, 38(11), 2643-2650.

24. Karri, R. R.; Sahu, J. N. J. Envi. Manage., 2018, 206, 178-191.

25. Wang, J.; Zheng, S.; Shao, Y.; Liu, J.; Xu, Z.; Zhu, D. J. Colloid Interface Sci., 2010, 349(1), 293-299.

26. Lingamdinne L. P.; Koduru, J. R.; Chang, Y. Y.; Karri, R. R. J. Mol. Liq., 2018, 250, 202-211.

27. Karri, R. R.; Sahu, J. N. J. Mol. Liq., 2018, 265, 592-602.

28. Bhattacharya, K.; Parasar, D.; Mondal, B.; Ded, P. Sci. Rep., 2015, 5(1), 1-9.http://dx.doi. org/10.1038/srep17072. 